\title{
Quality of Work Life: A Significant Dimension of Non-Financial Compensation or Managers' Tool to Generate Reciprocity
}

\section{(A Comparative Study among Pakistani Banking Professionals Having Low and High Levels of Perceived Organizational Support)}

\author{
Imran Ahmed Shahzad \\ Post graduate center, Limkokwing University of Creative Technology, \\ Cyberjaya, Malaysia \\ Valliapan Raju \\ Post graduate center, Limkokwing University of Creative Technology, \\ Cyberjaya, Malaysia
}

Muhammad Farrukh

Faculty of Business and Management, Cyberjaya University College of Medical Sciences, Malaysia

Nagina Kanwal

Post graduate center, Limkokwing University of Creative Technology,

Cyberjaya, Malaysia

Muhammad Ikram

Post graduate center, Limkokwing University of Creative Technology,

Cyberjaya, Malaysia. 
Received: May 15, 2018 Accepted: July 12, 2018 Online published: July 23, 2018

doi:10.5296/ijhrs.v8i3.13137

URL: https://doi.org/10.5296/ijhrs.v8i3.13137

\begin{abstract}
With an aim to test reciprocity between non-financial elements of compensation and productivity outcomes, in the presence of perception about organizational support theory, Data had been collected at primary level by a questionnaire, from a sample of 525 banking professionals from big ten Pakistani banks, and same had been analyzed by smartPLS. Results showed that all relationships among study variables are highly responsive to the perception about organizational support. Quality of work life creates reciprocity with employee performance but their magnitudes get affected where practioners need to pay specific attention on employee perception about organizational support.
\end{abstract}

Keywords: compensation, non-monetary rewards, quality of work life, job satisfaction, perceived organizational support, employee performance

\title{
1. Background
}

Mutual expectations of employees and employer may contradict and cause confliction that in return may impede the achievement of pre-set organizational goals, if not administered uprightly. Humanization of work place seems essential in order to ensure alignment between employer and employees. Business managers highlighted that humanization of working place is difficult because of the market pressures like competition, cost cutting, profit maximization and divisions of human in consumers \& workers. But firms need to understand that it is the significant aspect of human life as human expect and prefer good behavior and care from each other. Solution seems to be lied in humanizing working environment and increasing the quality of work life, as some workers spend months, years and some whole life with one firm. This relationship is also explained by expectancy theory.

Employees expect salary and related benefits while firms are concerned about productivity / performance delivered by employees. Firms are usually very clear about what they would contribute but remain unsure about workers' attitudes and reactions. Employees use to exert the level of efforts keeping in mind the overall firm's attitude toward their care of workers' wellbeing, provision of the quality of working environment and overall how workers are treated at workplace. Organizational researchers have termed this concept as gift exchange. Resources are exchanged with a hope to receive back in the desired form by the donor (Gouldner, 1960). Cropanzano \& Mitchell (2005) explains this relationship or reciprocity of expectation that "Social exchange theory describes a series of interactions that are interdependent, contingent on the actions of the social exchange partners.

Employees usually perceive their employer to be caring for their work and effort. This perception helps in boosting the level of efforts for accomplishment of organizational objectives and predefined targets (Eisenberger, Huntington, Hutchinson, \& Sowa, 1986; Hutchison et al,. 1986; Shore \& Shore (1995); Bartram, Karimi, Leggat \& Stanton, 2014; 
Qunchao Lv \& Xinli Xie, 2017) and employees are rewarded for their efforts and performing assigned tasks (Asrar-ul-Haq and Kuchinke, 2016). Employers usually reward their employees either in monetary or non monetary terms. Whereas many external forces like regulators are involved while deciding and making monetary payments. On the other hand non monetary rewards are generally facultative and relying on the budget of the firm as well as on the perception of the management. This research is addressing the discretionary arrangements by firms in the shape of quality of work life while a returns as a result of generated reciprocity in shape of employee performance.

Cost of talent pool is so high in all organizations that it cannot afford low level of employee performance. In order to keep them working in desired directions organizations need to get them motivated and satisfied from their job. Different researchers have shown a strong relationship among all these steps (Chiang, Hsu \& Shih, 2015; Farh, Hackett, Liang, 2007). So, firms need to concentrate on the ways that can strengthen these relationships. This study can provide the strong basis where employee performance can be influenced. Tor E., (2005) explains that Base salary, Bonuses, Premium pay, Other 'Pay' refers to total compensation, and the only industry in which compensation is significantly above average is banking.

Services sector contributed 54.6\% of Pakistan's total GDP, and employs $36.6 \%$ of the workforce. Industry has brought about significant job growth opportunities in services sector (www.osec.ch on June 28, 2011).The government's initiative of the privatization of telecommunications, utilities and banking. Since 2000, more than 40 transactions of mergers and acquisitions have been executed within banks and between banks and non-bank finance companies. For this study top ten banks of Pakistan are selected which comprising over more than $70 \%$ of the market share since last ten years which means this study will illustrate more than $70 \%$ trends in banking industry. Banking industry of Pakistan can be broadly categorized into Scheduled Banks and Non-Banking Financial Institutions (NBFIs). The banking sector comprised of thirty four (34) scheduled banks (21 local private banks, 5 public sector commercial banks and 4foreign banks) and 4 specialized banks with a total number of twelve thousands nine hundreds and ninety three (12993) branches throughout the country having 40.5 million $(46,493,242)$ of deposit account holders. This study will unfold the nature of relationship between organizational cost on humanization of working environment and reciprocity it would generate where in return firms and enjoy employee performance. In this way it will highlight few new directions for the future researchers along with guidance to practioners.

\section{Literature Review}

Study of compensation is important to organization as (Hollenbeck \& Wright, 1993) from employee point of view is the main reason they come to workplace while from the employer point of view compensation is the most powerful tool furthering the organizational objective and it cost organization significantly. At the same time employees deem it sign of status and success, they also use to compare it with others specifically people doing same type of job within and outside the organizations. Higher salaries are paid to the employees who handle complex responsibilities in organization and these are the employees who get progress in 
career growth. Therefore designing compensation plans is getting tough day by day. Designing compensation plans involve (a) identifying the organization's primary goals, (b) selecting organizational structure, and (c) an approach that fits organizational structure and implementation (Conley \& Odden, 1995). Many other studies shows a relationship among compensation, motivation, employees individual performance and finally organizational performance as compensation Plan are the key strategic area for any organizations which impacts an employer's ability to attract applicants, retain employees, and ensure optimal level of performance from employees in meeting the organization's strategic objectives (Mello \& Jaffrey, 2005; Shahzad A. imran 2008; Donald A. Hantula, Charles R. Crowell,. 2016).

Study of rewards and compensation has been under consideration of business as well as economic researcher and the amount of attention has remained quite high in the last decade (TheEconomist.com 2005; Dagens Nyheter, 2007). Compensation can be identified as anything that an employer can and willing to offer to its employees in exchange of their efforts and skills, which can further be financial (direct payments in shape of salaries and indirect payments in shape of benefits) and non financial (protection programs, employee involvement in decision making, effective supervision, recognition, training opportunities, supportive, nurturing company culture). (Cascio F. 2003). Compensation refers to all forms of pay or rewards going to employees and arising from their employment. (Thomas Pattern 1977). Monetary rewards are not enough to compel people to perform at their full potential; there are other elements like promotional opportunities, work satisfaction and turnover intentions etc. (Herpen et. al (2003); Hertzberg \& Frederick, 2003; Gaskell Carole, 2001 and Bardoel, De Cieri, \& Mayson, 2008).

Humanistic work environment can create a win-win situation for both employees and the organization. If members of any organization are happy, the will be more productive, more creative, and more fulfilled. Personal fulfillment and high morale are closely linked to outstanding performance and therefore, have a direct impact on organizational success (Jean clued et al., 2003 and Aries, Veitch, \& Newsham., 2010). Investigations and research results are reporting continuously that work life studies are important for the understanding and crafting of organizational environment as "There has been a growing trend to examine individual level values in order to better understand the attitudes and behaviors of employees in the workplace, very few studies have examined whether and how individual values are related to the interface between work and life" (Aaron Cohen, 2009 and Ahsan, et al., 2013). Yu Ru Hsu, (2011) The concept of quality of work life emerged in 1933 by a sociologist Elton Mayo as it started to pay attention to the employee working conditions in the context of organizational and employee performance. Latter till 2001 it remained under discussion of most of the researchers while after that the momentum for the exploration of this factor slowed down (Jean Martel \& Gilles, 2006). Personal characteristics and feelings about organizational arrangements can cause the different level or quality of work life (Hannif, Burgess \& Connell, 2008 and Alter, A., 2013).

Gender and experience with the same organization and overall of individual do not make any difference in job satisfaction level. Usually employees become dissatisfied by their job when they remain stagnant (Sarah Schulman, 2007). According to J. Christopher, Andrea A., \& 
Dorothea (2006), job satisfaction is a contingent feeling of an employee about his job which is some time pleasing (satisfied) and sometimes not (dissatisfied). Job satisfaction is also interchangeably used with the term "morale" as described by Armstrong Michael, (2006); Foster, Punjaisri \& Cheng, 2010). Job Characteristics Model (JCM, Hackman \& Lawler, 1971) highlighted give main job characteristics for job satisfaction which are; task identity, task significance, skill variety, autonomy, and feedback. Job satisfaction: The term "Job Satisfaction" refers to the attitudes and feelings people have about their work. Positive and favorable attitudes towards the job indicate job satisfaction. Negative and unfavorable attitudes towards the job indicated job dissatisfaction. As job satisfaction creates a good feel about a work, it is further deemed that job satisfaction will lead a positive change towards the employee performance. "Work-life conflict negatively effects job satisfaction. Further to this it is extracted from the study that perceived supervisor support and internal locus of control have direct effects on job satisfaction. In extension to this, it is explored that perceived support (perceived) and individual own locus of control also significantly moderate the relationship between work-family conflict and job satisfaction (Yu Ru Hsu, 2011).

Productivity is said to be the behaviors, employees show towards their duties and responsibilities. In this way behaviors are supposed to be very well linked with compensation as (Andrew G. Spohn 1994) highlighted that the key of making compensation system more effective is to be sure that they are directly connected to expected behavior. Opposing sentiment are also found in literature where some researcher argue that if pay and productivity are linked to each other it may damage intrinsic rewards a person gets from doing the job well (Herbert, 1975). Study of pay, job satisfaction and productivity is important as it involves different aspects that may result in absenteeism and turnover intentions of employees. Rewarding a performance is being explored in many contexts by different researcher in the areas of both human resources management as well as social scientists. Bonuses for good performances may be external rewards, extra payment, or simply getting the reward sooner (Ohen, Kaplan \& Sela, 2008). Satisfaction can be result of performance (Locke, 1970) but satisfaction can only be felt if performance is well rewarded (Cherrington, Reitz \& Scott, 1971). Jared D. Harris, 2008; Marinko, et al., 2015; Burnett, Chiaburu, Shapiro, \& Li, 2015) Compensation must be linked with performance. If workers perform at the given standard, tested and found satisfactory their compensation must be adjusted and paid accordingly. Hayward et al. (2004) \& Jared D. Harris, (2008). Compensation system, directly linking employer's compensation to employees' performance, is forecasted as the leading source of increased productivity (Lazear, 1999; Baker, Jensen, \& Murphy, 1988). Brayfield \& Crocket, (1995). Productivity is not an end but a means to the end or achieving goals Vroom (1964). The existing vast literature could not fully establish and recommend the strong correlation between job satisfaction and employees productivity.

According to Hekman, Steensma, Bigley, \& Hereford, (2009), perceived Organizational Support puts highly positive impact over employees' job performance. Concept of organizational support was introduced by an American expert in psychology and behavioral sciences, Eizenberger in 1986. The concept got momentum in early 90s and remain focused by researchers of organizational behavior. In the context of Organizational Support Theory, 


\section{MInstitute Macrink $_{\text {Ins }}$}

International Journal of Human Resource Studies

ISSN 2162-3058

2018, Vol. 8, No. 3

based on the organizational rules, regulations, rewarding strategies and personification employees start analyzing the ways how they are being treated (favorably or unfavorably) by their firms and further link this indication towards the extent to which firms value employees' contribution and efforts and care they receive for their well being. O'Neill Olivia (2009) identified that low level of perceived organizational support yields anger in employees and results in absenteeism, job accidents, inventory loss, alcohol consumption and turnover. Hekman et al. (2009) "Perceived Organizational Support had the most positive influence on employees' work performance when employees strongly identified with the organization and weakly identified with the profession". When employees are actively identified with the organization rather than their profession. Sound evidence is witnessed in literature that perceived organizational support is such a variable that influences every model of employee behaviour in any organizational set up (Casper, 2002; Witt, Carlson \& Dawn, 2006; Erdogan, Berrin, Enders \& Jeanne, 2007; Tucker, Chmiel, Turner, Nick, Hershcovis, Sandy, Stride \& Chris 2008; Shahzad, Farrukh, Kanwal \& Sakib (2018); Carmel \& Scott, 2009; Guiyao, Bingjie, Fang, Yang, 2017).

Based on the above literature review following hypothesis are developed; H1: Quality of Work Life (QWL) has positive influence on employee Job Satisfaction (JS). H1a: Relationship between Quality of Work Life (QWL) and employee Job Satisfaction (JS) is stronger for the individuals having high perceived organizational support than for those having low perceived organizational support. H2: Job Satisfaction (JS) has positive influence on Employee Performance (EP). H2a: Relationship between employee Job Satisfaction (JS) and Employee Performance (EP) is stronger for the individuals having high perceived organizational support than for those having low perceived organizational support. H3: Job Satisfaction (JS) mediates the relationship between Quality of Work Life (QWL) and Employee Performance (EP). H4: Quality of Work Life (QWL) has positive influence on Employee Performance (EP). H4a: Relationship between Quality of Work Life (QWL) and Employee Performance (EP) is stronger for the individuals having high perceived organizational support than for those having low perceived organizational support. H5: POS moderates the relationship between Quality of Work Life (QWL) and job satisfaction (JS). H6: POS moderates the relationship between job satisfaction (JS) and employee performance (EP). H7: POS moderates the relationship between Quality of Work Life (QWL) and employee performance (EP).

Based on the above literature review theoretical model is developed. Figure-1 shows the theoretical framework along with hypothetical relationships among study variables. 


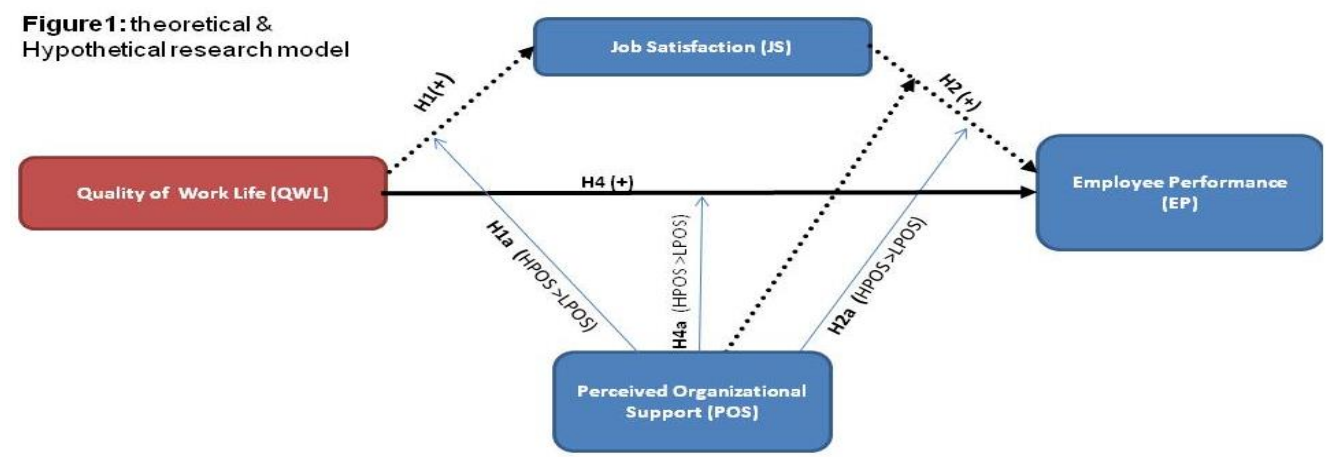

Figure 1. Theoretical \& Hypothetical research model

\section{Methodology}

Middle level managers and employees of top ten Banks of Pakistan (comprising of public, private as well as multinational banking corporations is the population of this study because the growth rate of these ten corporations was significantly higher during past ten years. Table-1 provides details on collective market share of the organization ranging from 2007 to 2016. Overall there were ten banks with 8761 branch network throughout Pakistan. Out of these 2835 branches were present in three big cities of Pakistan. Two hundreds and eighty three (283) branches out of 8761 branches of top ten banks were selected using judgmental sampling technique. This sample consisted of $10 \%$ of the total population of the selected banks in three big cities. Middle managers and supervisors were taken as respondents of the study. As detailed in table-2, a sample population of 664 respondents was collected comprising $58.5 \%$ response rate. 525 out of 664 questionnaires were found completely and properly filled comprising completely filled response rate of $46.30 \%$.

Table 1. Top Ten Pak-Banks (Market Share in industry)

\begin{tabular}{c|c|c}
\hline S/N & Years & Market Share (percentage) \\
\hline 1 & $\mathbf{2 0 0 7}$ & $76.50 \%$ \\
\hline 2 & $\mathbf{2 0 0 8}$ & $75.80 \%$ \\
\hline 3 & $\mathbf{2 0 0 9}$ & $76.70 \%$ \\
\hline 4 & $\mathbf{2 0 1 0}$ & $75.10 \%$ \\
\hline 5 & $\mathbf{2 0 1 1}$ & $73.10 \%$ \\
\hline 6 & $\mathbf{2 0 1 2}$ & $72.50 \%$ \\
\hline 7 & $\mathbf{2 0 1 3}$ & $75.10 \%$ \\
\hline 8 & $\mathbf{2 0 1 4}$ & $74.60 \%$ \\
\hline 9 & $\mathbf{2 0 1 5}$ & $73.60 \%$ \\
\hline 10 & $\mathbf{2 0 1 6}$ & $73.00 \%$ \\
\hline
\end{tabular}

Source: State Bank of Pakistan

It is explanatory study, based on primary data where questionnaires have been used to collect the data through quantitative research technique. The questionnaires is consisted of two parts; wherein the first part is based on 10 demographic related questionnaires being asked from the employees and the second part is comprised of 42 employees related questions covering four areas; Quality of Work Life (QWL), Job Satisfaction (JS), Employee Performance (EP) and 
Perceived Organizational Support (POS). Personal construction theory has been adopted. As per this theory everyone is capable of having different perceptions based on his personal experiences and studies regarding various facets of work and life. According to the original proponent of the theory, Kelly, G. A. (1955), the individual has the 'freedom to choose' the implication that one wishes or prefers. According to Chen, Lawler \& Bae, (2005), Asian respondents generally go for the central option while filling the questionnaires containing 5 or 7 response options. Hence, Six-Point Likert scale ranging from strongly Disagree (1) to strongly agree has been adopted to eliminate the central tendency bias. Composite Reliability $(\mathrm{CR})$ values for the variables were found significant $(\mathrm{QWL}=\mathbf{0 . 7 4 0 ,} \mathbf{J S}=\mathbf{0 . 7 6 2}, \mathbf{E P}=\mathbf{0 . 8 0 9} \&$ $\mathbf{P O S}=\mathbf{0 . 7 8 0}$ ).

Table 2. Sample of middle level employees from top ten banks

\begin{tabular}{l|c|c}
\hline & Number & Response rate (\%) \\
\hline No of studied banks & 10 & \\
\hline Total Number of branches & 8990 & \\
\hline Branches in 03 cities (Karachi, Lahore \& Islamabad) & 2835 & \\
\hline No of middle level Employees & 9890 & \\
\hline Total No of employees contacted for survey & 1134 & \\
\hline No of respondents & 664 & \\
\hline No of respondents Dropped during data screening & 139 & \\
\hline Valid number of respondents & 525 & $\mathbf{4 6 . 3 0}$ \\
\hline
\end{tabular}

In-order to measure Quality of Work Life (QWL), eighteen (18) research items was used in total. Twelve research items developed by Chen and Farh (2000) used to cover the four dimensions of quality of work life (work/life balance, job characteristics, supervisory behavior and compensation \& benefits). Research items were; My current job does not interrupt my family life, The over time of my current job is reasonable, The work overload of my current job is reasonable, My job permits me to decide on my own how to go about doing the work, My job is challenging, My job is creative and meaningful, My supervisor instructs me how to improve my job, My supervisor acknowledges me when I perform good, My supervisor assists to solve my job problems, I am fairly rewarded compared to similar jobs in my organization, I am fairly rewarded compared to similar jobs outside my organization and My organization cares about employee welfare. In-order to testify working environment six research items were used developed and implemented by Sigvard et al. (1983). Research items were covering workplace, light, noise, Air, Health care, medical services and accident prevention arrangements. Research items were; My workplace has proper light arrangement, My organization has controlled the noise, My organization has arrangement for the fresh air, My organization has health care arrangements at workplace, My organization has medical services at workplace and My organization has taken accident preventions.

Minnesota satisfaction questionnaire 1967, (self reported questionnaire) was used to measure intrinsic, extrinsic and overall job satisfaction. Research items were; The chance to try my own method of doing the job, The competence of my supervisor in making decisions, Being able to do things that don't go against my conscience, The way my organization provides job security, The chance to do something that makes use of my abilities, The way company policies are put into practice, My pay and amount of work I do, The chances for advancement 
on this job, The way my co-workers get along with each other, The praise I get for doing a good job, The feeling of accomplishment I get from the job and Overall Job satisfaction. Employee performance was measured by self reported questionnaire containing six items from six dimensions (extra work, quality of work, hard work, intention to do the job, higher performance \& higher efforts). These dimensions were adopted from the earlier work of Kuvaas (2006). Research items were; I often put extra effort in carrying out my job, The quality of my work is top-notch, I try to work as hard as possible, I intentionally put a great deal of effort in carrying out my job, I deliver higher quality than what can be expected and I almost always put in more effort than what can be characterized as an acceptable level of effort. For measuring Perceived Organizational Support (POS) six items from six different dimensions were adopted from the Survey of Perceived Organizational Support (SPOS) by Hutchison, et al.,1986 and Eisenberger, et al., 1990 . These six dimensions include concern about employees, overall employee satisfaction, employee goals and values, employee opinion, employee wellbeing and noticing employee's performance. Research items were; My bank's management shows concerns for me, My bank's management cares about my well being, My bank's management cares about my overall satisfaction at work, My bank's management strongly consider my goals and values. My bank's management cares about my opinion and Even I did a minor job my bank's management takes notice.

Data Analysis and Results: Cluster analysis / scattered plots are given in Figures 2, 3, 4 \& 5, showing positive associations among studied variables. These positive relations were well assembled around mean values and. The data is positively distributed but some responses were found outliers depicting some variations and distortions.
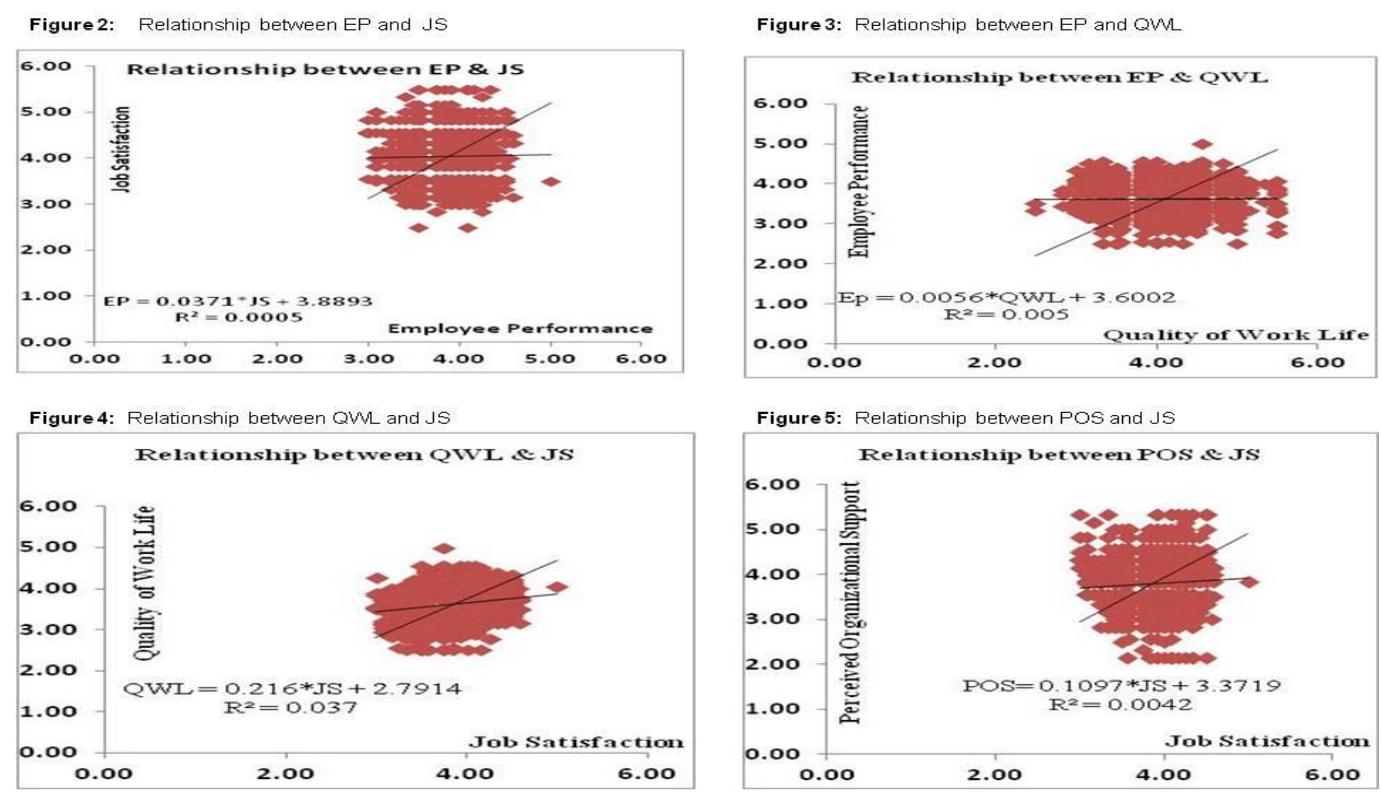

Descriptive \& inferential statistics highlighted number of observations, mean, variance and standard deviation. 


\section{Ml Macrothink}

International Journal of Human Resource Studies

ISSN 2162-3058 2018, Vol. 8, No. 3

Table 3. Descriptive statistics

\begin{tabular}{l|c|c|c|c}
\hline \multicolumn{1}{c|}{ Variables } & $\mathrm{N}$ & Mean & SD & Variance \\
\hline Age & 525 & 3.25 & 0.97 & 0.94 \\
\hline Gender & 525 & 0.26 & 0.44 & 0.2 \\
\hline years of experience & 525 & 3.57 & 1.06 & 1.12 \\
\hline Academics & 525 & 3.52 & 1.05 & 1.1 \\
\hline Total experience & 525 & 4.05 & 0.93 & 0.86 \\
\hline Income & 525 & 3.51 & 1.25 & 1.57 \\
\hline No. of employees & 525 & 3.37 & 0.94 & 0.89 \\
\hline Employment & 525 & 3.09 & 0.91 & 0.84 \\
\hline Position & 525 & 3.09 & 0.72 & 0.52 \\
\hline Marital Status & 525 & 0.54 & 0.5 & 0.25 \\
\hline QWL & 525 & 3.62 & 0.36 & 0.13 \\
\hline JS & 525 & 3.82 & 0.33 & 0.11 \\
\hline EP & 525 & 4.03 & 0.54 & 0.29 \\
\hline POS & 525 & 3.79 & 0.58 & 0.33 \\
\hline
\end{tabular}

In table-3 descriptive statistics resulted that mean varies between variables from 3.09 to 4.05 and standard deviation varies from 0.33 to 1.25 which conforms the finding of scatter diagram that the collected data is having variations. By examining the values derived from descriptive statistics and grouped in table 3 like; (QWL-mean=3.62 \& $\mathrm{SD}=0.36$; JS-mean=3.82 \& SD=0.33; EP-mean=4.03 \& SD=0.54 \& POS-mean=3.79 \& SD=0.58), it becomes easy to evaluate how the values are near or far from the mean values of the research variable. The low value of standard deviation represents that all the participants agreed to the appropriateness of given options of each statement.

Table 3a. Correlation Results

\begin{tabular}{l|c|c|c|c}
\hline & QWL & JS & EP & POS \\
\hline QWL & 1 & & & \\
\hline JS & 0.36 & 1 & & \\
\hline EP & 0.199 & 0.43 & 1 & \\
\hline POS & 0.271 & 0.32 & 0.51 & 1 \\
\hline
\end{tabular}

Results of the correlation are given in table 3a. Highest positive correlation is found between EP and POS (0.51) while lowest positive correlation is found between EP and QWL. Demographic characteristics of the respondents are grouped in table 4. 


\section{Macrothink}

International Journal of Human Resource Studies

ISSN 2162-3058

2018, Vol. 8, No. 3

Table 4. Demographic characteristics of respondents

\begin{tabular}{|c|c|c|c|c|c|c|c|c|c|c|c|c|c|}
\hline \multirow{2}{*}{\begin{tabular}{l}
\multicolumn{1}{c}{ Variables } \\
Academic \\
background
\end{tabular}} & \multicolumn{2}{|c|}{ Low POS } & \multicolumn{2}{|c|}{ High POS } & \multicolumn{2}{|c|}{ Total } & \multirow{2}{*}{$\begin{array}{l}\text { Variables } \\
\text { Employment } \\
\text { status }\end{array}$} & \multicolumn{2}{|c|}{ Low POS } & \multicolumn{2}{|c|}{ High POS } & \multicolumn{2}{|c|}{ Total } \\
\hline & $\mathbf{N}$ & $\%$ & $\mathbf{N}$ & $\%$ & $\mathbf{N}$ & $\%$ & & $\mathbf{N}$ & $\%$ & $\mathbf{N}$ & $\%$ & $\mathbf{N}$ & $\%$ \\
\hline High School & 2 & $8 \%$ & 24 & $92 \%$ & 26 & $5 \%$ & contractual & 101 & $56 \%$ & 79 & $44 \%$ & 180 & $35 \%$ \\
\hline Bachelor & 86 & $32 \%$ & 182 & $68 \%$ & 268 & $52 \%$ & permanent & 64 & $30 \%$ & 150 & $70 \%$ & 214 & $41 \%$ \\
\hline Master & 91 & $44 \%$ & 114 & $56 \%$ & 205 & $40 \%$ & Project base & 104 & $79 \%$ & 27 & $21 \%$ & 131 & $25 \%$ \\
\hline M. Phil & 3 & $21 \%$ & 11 & $79 \%$ & 14 & $3 \%$ & Seasonal & 0 & $0 \%$ & 0 & $0 \%$ & 0 & $0 \%$ \\
\hline Others & 3 & $25 \%$ & 9 & $75 \%$ & 12 & $1 \%$ & Internee & 0 & $0 \%$ & 0 & $0 \%$ & 0 & $0 \%$ \\
\hline TOTAL & 185 & & 340 & & 525 & $100 \%$ & TOTAL & 269 & & 256 & & 525 & $100 \%$ \\
\hline $\begin{array}{l}\text { Total years of } \\
\text { Experience }\end{array}$ & & & & & & & Age Groups & & & & & & \\
\hline less than 05 & 15 & $16 \%$ & 80 & $84 \%$ & 95 & $18 \%$ & Below 25 & 41 & $49 \%$ & 42 & $51 \%$ & 83 & $15 \%$ \\
\hline $5-10$ & 156 & $43 \%$ & 208 & $57 \%$ & 364 & $70 \%$ & $26-35$ & 95 & $45 \%$ & 118 & $55 \%$ & 213 & $41 \%$ \\
\hline $11-16$ & 17 & $43 \%$ & 23 & $58 \%$ & 40 & $8 \%$ & $26-45$ & 58 & $33 \%$ & 120 & $67 \%$ & 178 & $34 \%$ \\
\hline $16-20$ & 9 & $60 \%$ & 6 & $40 \%$ & 15 & $2 \%$ & $46-55$ & 5 & $18 \%$ & 23 & $82 \%$ & 28 & $5 \%$ \\
\hline 21 and above & 7 & $64 \%$ & 4 & $36 \%$ & 11 & $2 \%$ & 56 and above & 1 & $4 \%$ & 22 & $96 \%$ & 23 & $6 \%$ \\
\hline TOTAL & 204 & & 321 & & 525 & $100 \%$ & TOTAL & 200 & & 325 & & 525 & $100 \%$ \\
\hline $\begin{array}{c}\text { Number of } \\
\text { employee }\end{array}$ & & & & & & & $\begin{array}{l}\text { Years of } \\
\text { experience-current }\end{array}$ & & & & & & \\
\hline less than 500 & 0 & $0 \%$ & 0 & $0 \%$ & 0 & $0 \%$ & less than 03 & 100 & $78 \%$ & 29 & $22 \%$ & 129 & $3 \%$ \\
\hline $500-1000$ & 0 & $0 \%$ & 0 & $0 \%$ & 0 & $0 \%$ & $3-6$ & 173 & $57 \%$ & 130 & $43 \%$ & 303 & $60 \%$ \\
\hline $1001-2000$ & 1 & $14 \%$ & 6 & $86 \%$ & 7 & $0 \%$ & $7-10$ & 2 & $6 \%$ & 30 & $94 \%$ & 32 & $25 \%$ \\
\hline $2001-3000$ & 11 & $10 \%$ & 100 & $90 \%$ & 111 & $21 \%$ & $11-14$ & 41 & $79 \%$ & 11 & $21 \%$ & 52 & $10 \%$ \\
\hline Above 3000 & 53 & $13 \%$ & 354 & $87 \%$ & 407 & $78 \%$ & 15 and above & 4 & $44 \%$ & 5 & $56 \%$ & 9 & $2 \%$ \\
\hline TOTAL & 65 & & 460 & & 525 & $100 \%$ & TOTAL & 320 & & 205 & & 525 & $100 \%$ \\
\hline Position & & & & & & & Income per month & & & & & & \\
\hline Employee & 0 & $0 \%$ & 0 & $0 \%$ & 0 & $0 \%$ & less than 25000 & 8 & $53 \%$ & 7 & $47 \%$ & 15 & $3 \%$ \\
\hline Supervisor & 36 & $54 \%$ & 31 & $46 \%$ & 67 & $12 \%$ & $26000-50000$ & 232 & $74 \%$ & 82 & $26 \%$ & 314 & $60 \%$ \\
\hline AM & 45 & $35 \%$ & 83 & $65 \%$ & 128 & $25 \%$ & $51000-75000$ & 54 & $41 \%$ & 78 & $59 \%$ & 132 & $25 \%$ \\
\hline Manager & 54 & $24 \%$ & 172 & $76 \%$ & 226 & $44 \%$ & $76000-100000$ & 11 & $21 \%$ & 41 & $79 \%$ & 52 & $10 \%$ \\
\hline Branch Manager & 49 & $47 \%$ & 55 & $53 \%$ & 104 & $20 \%$ & Above 100000 & 4 & $33 \%$ & 8 & $67 \%$ & 12 & $2 \%$ \\
\hline $\begin{array}{l}\text { TOTAL } \\
\end{array}$ & 184 & & 341 & & 525 & $100 \%$ & \begin{tabular}{|l|} 
TOTAL \\
\end{tabular} & 309 & & 216 & & 525 & $100 \%$ \\
\hline Marital status & & & & & & & Gender & & & & & & \\
\hline Single & 71 & $51 \%$ & 67 & $49 \%$ & 138 & $26 \%$ & Female & 9 & $15 \%$ & 53 & $85 \%$ & 62 & $11 \%$ \\
\hline Married & 99 & $26 \%$ & 288 & $74 \%$ & 387 & $74 \%$ & Male & 134 & $29 \%$ & 329 & $71 \%$ & 463 & $89 \%$ \\
\hline TOTAL & 170 & & 355 & & 525 & $100 \%$ & TOTAL & 143 & & 382 & & 525 & $100 \%$ \\
\hline
\end{tabular}

The hypothesized model was tested by applying PLS-SEM technique and using Smart PLS 3.0 software (Ringle, Wende, \& Becker, 2015). PLS SEM has been utilized to produce the results. The Partial Least Squares technique is a powerful technique widely used in prior studies (Farrukh, Khan, et al., 2017; Farrukh, Chong, Mansori, \& Ravan Ramzani, 2017; Farrukh, Wei Ying, \& Abdallah Ahmed, 2016; Farrukh, Ying, \& Mansori, 2016, 2017; Riaz, Farrukh, Rehman, \& Ishaque, 2016; Shahzad, Farrukh, Kanwal, \& Sakib, 2018).

All the variables were based on the first order reflective constructs. PLS-SEM involves two step assessments of measurement as well as structural model (Andersen and Gerbing, 1988). 
Table 5. Quality Criteria for measurement model

\begin{tabular}{|c|c|c|c|c|c|c|}
\hline Constructs & Items & Loadings & AVE & $\begin{array}{l} \pm \sqrt{ } \text { AVE } / \\
A^{\wedge} E^{\wedge} 0.5\end{array}$ & $\mathrm{CR}$ & Croanbach $\alpha$ \\
\hline QWL & $\begin{array}{l}\text { QWL1 } \\
\text { QWL2 } \\
\text { QWL3 } \\
\text { QWL4 } \\
\text { QWL5 } \\
\text { QWL6 } \\
\text { QWL7 } \\
\text { QWL8 } \\
\text { QWL9 } \\
\text { QWL10 } \\
\text { QWL11 } \\
\text { QWL12 } \\
\text { QWL13 } \\
\text { QWL14 } \\
\text { QWL15 } \\
\text { QWL16 } \\
\text { QWL17 } \\
\text { OWL18 }\end{array}$ & $\begin{array}{l}0.7678 \\
0.7293 \\
0.6287 \\
0.8145 \\
0.7551 \\
0.5631 \\
0.912 \\
0.8094 \\
0.8811 \\
0.7781 \\
0.7123 \\
0.7234 \\
0.7412 \\
0.7257 \\
0.7543 \\
0.7512 \\
0.7645 \\
0.7532\end{array}$ & 0.547 & 0.740 & 0.861 & 0.748 \\
\hline JS & $\begin{array}{r}\text { JS1 } \\
\text { JS2 } \\
\text { JS3 } \\
\text { JS4 } \\
\text { JS5 } \\
\text { JS6 } \\
\text { JS7 } \\
\text { JS8 } \\
\text { JS9 } \\
\text { JS10 } \\
\text { JS11 } \\
\text { JS12 }\end{array}$ & $\begin{array}{l}0.8123 \\
0.7543 \\
0.7342 \\
0.8314 \\
0.8123 \\
0.7543 \\
0.7342 \\
0.8123 \\
0.7543 \\
0.7342 \\
0.8314 \\
0.8123\end{array}$ & 0.58 & 0.762 & 0.886 & 0.854 \\
\hline EP & $\begin{array}{l}\text { EP1 } \\
\text { EP2 } \\
\text { EP3 } \\
\text { EP4 } \\
\text { EP5 } \\
\text { EP6 }\end{array}$ & $\begin{array}{l}0.7543 \\
0.7342 \\
0.7543 \\
0.7342 \\
0.7543 \\
0.7342\end{array}$ & 0.655 & 0.809 & 0.816 & 0.782 \\
\hline POS & $\begin{array}{l}\text { POS } 1 \\
\text { POS } 2 \\
\text { POS } 3 \\
\text { POS } 4 \\
\text { POS } 5 \\
\text { POS } 6\end{array}$ & $\begin{array}{l}0.8145 \\
0.8297 \\
0.8392 \\
0.7723 \\
0.7938 \\
0.8106\end{array}$ & 0.608 & 0.780 & 0.953 & 0.855 \\
\hline
\end{tabular}

Firstly, the measurement model was assessed by inspecting convergent validity (CV), Discriminant validity (DV), reliability and internal consistency (Hair et al., 2016). The degree of items to measure the latent construct was assessed by internal consistency and reliability (Hair et al., 2016). The scores of Composite reliability (CR) were analyzed for estimating the measurement model. The composite reliability (CR) values for the variables were found significant $(\mathrm{QWL}=0.861, \mathrm{JS}=0.886, \mathrm{EP}=0.856 \& \mathrm{POS}=0.953)$. Similarly, it was also assessed by the value of Average Variance Extracted (AVE) and square root values for AVE 


\section{Macrothink}

are 0.5 or above. The values are given in Table 5 .

Table 6. Fornell Larcker criteria

\begin{tabular}{l|l|l|l|l}
\hline & QWL & JS & EP & POS \\
\hline QWL & $\mathbf{0 . 7 4}$ & & & \\
\hline JS & 0.36 & $\mathbf{0 . 7 6 2}$ & & \\
\hline EP & 0.199 & 0.43 & $\mathbf{0 . 8 0 9}$ & \\
\hline POS & 0.271 & 0.32 & 0.51 & $\mathbf{0 . 7 8}$ \\
\hline
\end{tabular}

Note: diagonals represent ${ }^{\sqrt{ }}$ AVE

of the AVE while the other entries represent the correlation

Discriminant validity is measured after verifying the convergent validity by using the method of Fornell \& Larcker (1981). Discriminant validity or divergent validity is the measure of difference among constructs. This is assessed by comparing the value of AVE and square root value of AVE with correlation as given in Table 6. If the value of AVE square root is greater than the values in the row and columns for the particular construct then Discriminant validity exists. The values shown in Table 6 depict that there exists satisfactory level of Discriminant validity.

Table 7. Testing the hypotheses

\begin{tabular}{|c|c|c|c|c|}
\hline Hypothesis & Statements & Beta & $\begin{array}{c}t \\
\text { values }\end{array}$ & Result \\
\hline $\mathrm{H} 1$ & Quality of Work Life (QWL) has positive influence on employee Job Satisfaction (JS). & 0.211 & 4.62 & Supported \\
\hline $\mathrm{H} 2$ & Job Satisfaction (JS) has positive influence on Employee Performance (EP) & 0.196 & 3.23 & Supported \\
\hline $\mathrm{H} 4$ & Quality of Work Life (QWL) has positive influence on Employee Performance (EP) & 0.261 & 4.71 & Supported \\
\hline
\end{tabular}

Causal relationship between QWL, JS, EP and POS was tested by measuring structural model. For that purpose value of R2 and beta values (path coefficients) were measured to examine the hypothesized relationship among variables (Hair et al., 2014). The process of bootstrapping was performed in order to obtain t-values and standard errors in order to authenticate the statistical implication (Hair et al., 2014; Hair et al., 2011). The value of R2 measures predictive accuracy of the model (Ang, Ramayah, and Amin, 2015) and also measures the percentage of variance found in the dependent variables as defined by the independent variables (Hair et al., 2010). While the values of Path Coefficient provide the measure of change in the dependent variable by each independent variable (Hair et al., 2010; Hair et al., 2006; Pallant, 2007). R Square (R2) explains the variance, which is 0.241. It means that QWL explained $24.1 \%$ of the variance in EP. Based on the above discussions, hypotheses are either accepted or rejected. Summary of the findings is provided in table 7. 


\section{Macrothink}

International Journal of Human Resource Studies ISSN 2162-3058 2018, Vol. 8, No. 3

Table 8. Mediation results

\begin{tabular}{|c|c|c|c|c|}
\hline \multicolumn{2}{|c|}{ Direct Effect } & $95 \%$ confidence interval of direct affect & T value of direct effect & Significance? \\
\hline $\begin{array}{l}\text { QWL } \\
->E P\end{array}$ & 0.227 & {$[0.212-0.541]$} & 4.16 & Yes \\
\hline \multicolumn{2}{|c|}{ Indirect Effect } & $95 \%$ confidence interval of direct affect & $T$ value of direct effect & Significance? \\
\hline $\begin{array}{l}\text { QWL } \\
\text {-> EP }\end{array}$ & 0.181 & {$[0.196-0.440]$} & 3.71 & Yes \\
\hline
\end{tabular}

Results displayed in Table 8, after employing the bootstrapping method; JS mediates the mentioned relationship indicating support for $\mathrm{H} 3$. As new values/indirect effect are lower than the previous values/direct effect $(0.181<0.227)$ along with founded all t-values >1.96; it shows that JS mediates the relationship between QWL and EP. Therefore, hypotheses H3 is accepted.

Table 9. Comparison - Moderating role of POS

\begin{tabular}{c|c|c|c|c|c}
\hline \multirow{2}{*}{ Relationships } & \multicolumn{2}{|c|}{ Stage one } & \multicolumn{2}{c|}{ Stage two } & \\
\cline { 2 - 6 } & Without POS $(\beta)$ & t-values & With POS $(\beta)$ & t-values & change \\
\hline QWL -> JS & 1.76 & 1.99 & 1.81 & 3.21 & 0.05 \\
\hline JS -> EP & 1.59 & 2.75 & 1.62 & 3.95 & 0.03 \\
\hline QWL -> EP & 2.21 & 3.41 & 2.93 & 3.25 & 0.72 \\
\hline
\end{tabular}

Product indicator technique was applied using PLS path modeling in order to examine the moderating effect of POS on the relationship between QWL \& Js, JS \& EP and QWL \& EP. Two steps approach (Chen et al. 2008) is considered relevant for the study (exogenous construct) provided that moderating variable is measured formatively (Hensler \& chin 2010, Rigdon et al., 2010). As given in table-9; beta values on stage two are found higher than calculated on stage one $(1.81>1.76 ; 1.62>1.59 ; 2.93>2.21)$ along with $t$ values greater than the threshold $(1.99,2.75,3.41,3.21,3.95 \& 3.25>1.96)$; null hypotheses H5, H6 \& H7 are accepted.

Table 10. OLS Regression results-respondents having Low \& High Perceived Organizational Support

\begin{tabular}{c|c|c}
\hline \multirow{2}{*}{ Relationships } & Low POS Group & High POS Group \\
\cline { 2 - 3 } & $(\beta)$ & $(\beta)$ \\
\hline QWL -> JS & $2.13^{* *}$ & $2.59^{*}$ \\
\hline JS -> EP & $2.18^{*}$ & $2.33^{* *}$ \\
\hline QWL -> EP & $1.24^{*}$ & $1.87^{*}$ \\
\hline Intercept & 6.25 & 5.28 \\
\hline $\mathrm{e}$ & 0.241 & 0.39 \\
\hline Adjusted R $\mathrm{R}^{2}$ & 0.18 & 0.22 \\
\hline $\mathrm{F}$ & 0.006 & 0.01 \\
\hline
\end{tabular}

$\mathrm{N}=525$

** Significant at $5 \%$ 
* Significant at $10 \%$

In order to test the hypothesized relations among variables, total respondents were segregated in two groups as Low POS group (responses were marked from and 1-3 on six point scale) and as High POS group (responses were marked from 4 to 6 on Likert scale).Ordinary Least Square Regression is performed to compare respondents of each group and path coefficients ( $\beta$ values) are contrasted with adjusted $\mathrm{R}^{2}$ as shown in Table 10. When comparison between low and high POS groups is made all beta valued of study relationships are found higher in high POS group (2.59>2.13; $2.33>2.18 \& 1.87>1.24)$. Therefore null hypotheses H1a, H2a \& $\mathrm{H} 4 \mathrm{a}$ are accepted.

\section{Discussion and Conclusion}

Keeping in view demographic aspects of respondents; as the employee age increases, employment status keeps of moving and obviously his total years of experience increases which are quite natural and results are found arguing common sense phenomenon. More the years an employee serves with same organization he/she perceives more support from organization or it can be translated in another way i.e. if employees perceive organization support they spend more time with firms and gender difference make no impact POS even Pakistani cultural setting gives more importance to the female workers as compared to male workers. Female employees receive more facilities and organizational apprehension compulsorily from both the government of Pakistan and society as a whole. But at this point gender discrimination remains constant and Organizational Support is perceived to be equally available for all employees. Further to this employees' employment status is increasing they seem progressive in higher positions in organization further to this can be estimated that increase is qualification has very minimum chances of getting higher position. Correlation results also represent that banking professionals are expecting organizations to pay very serious attention towards their well being. Strong positive relationships of QWL with EP, JS and POS shows that quality of work life although effect all of the studied variables but its impact on EP is much greater then on others. This is also shows that if working environment of the organization is good, employees will be more satisfied with their jobs, they can be more performing on their jobs, and ultimately their chances of leaving the firm will be low. If the firm will produce high quality working environment that will increase performance of employees; at the end organizational performance will be improved, intimately. Further employees feel the organization is supporting them not only in its own goals but also considering the personal needs of them. These results are contradicting to findings in other settings (Feldman, 1985).

\section{Implications}

From Theoretical point of view this study has contributed in two ways; one, social exchange between firms and employees are greatly affected by organizational support theory. It advises researchers to consult perceived organizational support theory while studying and testing social exchange, non-monetary rewards \& related outputs and more specifically quality of work life arrangements between principals and agents. Secondly, as considerable mediating role of job satisfaction is found; when mediating role is ensured, the relationship of 
independent variable and dependent variable get weaker (Baron \& Kenny (1986). Same way it is to be considered that job satisfaction an element which can be used in creating more reciprocity in the study of compensation management.

As Quality of Work Life is found one of the most significant non monetary and partial discretionary rewards that a firm can offer to its employees, without involving financial costs. It provides basis to managers to help firms in shifting mind-set that concentration on employees is not to be considered as cost rather investment and yields ultimate result in shape of individual performance that latter on get grouped in departmental performance and at ultimately constitute organizational performance in overall. This study suggests the way to increase the employee outcomes by focusing on the employee perception about the organizational care. In presence of strong relationship between quality of work life and employees' performance, the perception of employees regarding organizational support can further yield and augment the performance of employees. This study is industry focused and provides guidelines to banking professional and organizations to devise compensation strategies according to the magnitude of the different reward practices and their overall contribution towards the employee outcomes. This study highlights finding which becomes the basis for the management to understand the significance of perceived organizational support even in the presence of good compensation plans. It provides evidence to the practioners to focus on creating the perception of the employees about organizational support. As this study is focused on the banking sector organizations, it provides the banking professionals about the preferences and behavioral aspects of employees in Government, Private and Multinational commercial banking organizations. Aggregate increase in the individual employee's performance finally leads to the increased overall organizational performance and considerable competitive advantage. Hence, all the managers responsible for boosting overall firm's performance can accomplish their assigned targets by concentrating on achieving employee performance through quality of work life.

\section{Limitations and Future Dimensions}

Employees' performance is measured while offering four non monetary rewards. The results of adjusted $\mathrm{R}^{2}$ depict that that other factors beyond our study also effect employees' outcome. The study is based on primary data as previously no study measured the moderating effect of POS in Pakistani setting therefore; perceptional measures for all variables were measured in our study. Same studies can further be conducted in other sector of the economy of Pakistan and results can be more generalized to the entire available domestic workforce. For more detailed and thoroughly investigated results this study can be extended and banking employees from human resources departments of these organizations can be involved. This can yield more clear understanding of the occurrence of the phenomenon.

\section{References}

Aaron, C. (2009). Individual values and the work/family interface: An examination of high tech employees. Journal of Managerial Psychology, 24(8), 813-830. Published by The Johns Hopkins University Press. 
Ahsan, N., Fie, D. Y. G., Foong, Y. P., \& Alam, S. S. (2013). Relationship between retention factors and affective organisational commitment among knowledge workers in Malaysia. Journal of Business Economic and Management, 14(5). https://doi.org/10.3846/16111699.2012.701226

Alter, A. (2013). Drunk tank pink: And other unexpected forces that shape how we think, feel, and behave. London: Penguin Press.

Anderson, J. C., \& Gerbing, D. W. (1988). Structural equation modeling in practice: A review and recommended two-step approach. Psychological Bulletin, 103(3), 411. https://doi.org/10.1037/0033-2909.103.3.411

Anderson, J. C., \& Gerbing, D. W. (1988). Structural Equation Modeling in Practice: A Review and Recommended Two-Step Approach. Psychological Bulletin, 103(3), 411-423. https://doi.org/10.1037/0033-2909.103.3.411

Andrew G. S. (winter 1994). The relationship of rewards systems and employee performance. Compensation and benefits management, 6, 128-32.

Ang, M. C. H., Ramayah, T., \& Amin, H. (2015). A theory of planned behavior perspective on hiring Malaysians with disabilities. Equality, Diversity and Inclusion: An International Journal, 34(3), 186-200. https://doi.org/10.1108/EDI-02-2014-0012

Aries, M. B. C., Veitch, J. A., \& Newsham, G. R. (2010). Windows, view, and office characteristics predict physical and psychological discomfort. Journal of Environmental Psychology, 30, 533-541. https://doi.org/10.1016/j.jenvp.2009.12.004

Armstrong, M. (2006). A handbook of Human Resources management, 10th edition, Kogan Page Limited, Philadelphia, USA. 234-235.

Armstrong, M. (2006). A handbook of Human Resources management, 10th edition, Kogan Page Limited, Philadelphia, USA. 234-235.

Asrar-ul-Haq, M., \& Kuchinke, K. P. (2016) 'Impact of leadership styles on employees' attitude towards their leader and performance: Empirical evidence from Pakistani banks', Future Business Journal. Elsevier, 2(1), 54-64. https://doi.org/10.1016/j.fbj.2016.05.002

Baker, G. P., Jensen, M. C., \& Murphy, K. J. (July 1988). Compensation and Incentives: Practice vs. Theory. Journal of Finance: Papers and Proceedings, 43, 593-616. https://doi.org/10.1111/j.1540-6261.1988.tb04593.x

Bardoel, E. A., De Cieri, H., \& Mayson, S. (2008). Bridging the research-practice gap: developing a measurement framework for work-life initiatives, Journal of Management and Organization, 14(3), 239-258.

Baron, R. M., \& Kenny, D. A. (1986). The moderator-mediator distinction in social psychological research: Conceptual, strategic, and statistical considerations. Journal of Personality and Social Psychology, 51, 1173-1182. Google Scholar, Crossref, Medline. https://doi.org/10.1037/0022-3514.51.6.1173 
Bartram, T., Karimi, L., Leggat, S. G., \& Stanton, P. (2014). Social identification: linking high performance work systems, psychological empowerment and patient care, The International Journal of Human Resource Management, 25(17), 2401-2419.

Brayfield, A. H., \& Crocket, W. H. (1995). Employee attitudes and employee performance. Psychological Bulletin, 52, 344-394.

Burnett, M. F., Chiaburu, D. S., Shapiro, D. L., \& Li, N. (2015). Revisiting how and when perceived organizational support enhances taking charge an inverted U-shaped perspective, Journal of Management, 41(7), 1805-1826. https://doi.org/10.1177/0149206313493324

Carmel, H., \& Scott, W. (2009). Implementing the Marketing Concept in Travel Organizations: The Important Moderating Influence of Perceived Organizational Support. Journal of Hospitality Marketing \& Management, 18(7),692-717. https://doi.org/10.1080/19368620903170232

Cascio, F. (2003). Managing Human Resources productivity, Quality of Work life profits, 6th edition, McGraw-Hill, Higher Education, New York.

Casper, W. J., Martin, J. A., Buffardi, L. C., \& Erdwins, C. J. (2002). Work-family conflict, perceived organizational support and organizational commitment among employed mothers. Journal of Occupational Health Psychology, 7(2),99-108. https://doi.org/10.1037/1076-8998.7.2.99

Chen, C. S., \& Farh, J. L (2000). Quality of work life in Taiwan; an exploratory study. Management Review, 19, 31-79.

Chen, F., Curran, P. J., Bollen, K. A., Kirby, J., \& Paxton, P. (2008). An empirical evaluation of the use of fixed cutoff points in RMSEA test statistic in structural equation models. Sociological Methods \& Research, 36(4), 462-494. https://doi.org/10.1177/0049124108314720

Chen, J., Lawler, J., \& Bae, J. (2005). Convergence in human resource systems: A comparison of locally owned and MNC subsidiaries in Taiwan. Human Resource Management, 44(3), 237-256. https://doi.org/10.1002/hrm.20069

Cherrington, D. L., Reitz, H. J., \& Scott, W. E. Jr. (1971). Effects of rewards and contingent reinforcement on satisfaction and task performance. Journal of applied psychology, 55, 531-536. https://doi.org/10.1037/h0032041

Chiang, Y. H., Hsu, C. C., \& Shih, H. A. (2015). Experienced high performance work system, extroversion personality, and creativity performance, Asia Pacific Journal of Management, 32(2), 531-549. https://doi.org/10.1007/s10490-014-9403-y

Chin, W. W. (1998). The partial least squares approach to structural equation modeling. Modern Methods for Business Research, 295(2), 295-336.

Christopher, C. J., Andrea, E. A., Dorothea, E. D. (2006). Integrating Situational and Dispositional Determinants of Job Satisfaction: Findings from Three Samples of 
Professionals. The Journal of Psychology, 140(4),363-395. https://doi.org/10.3200/JRLP.140.4.363-395

Cropanzano, R., \& Mitchell, M. S. (2005). Social exchange theory: An interdisciplinary review. Journal of Management, 31, 874-900. https://doi.org/10.1177/0149206305279602

Dagens, N. (2007). Bonus all valligare for top chefer. Business Venturing, 7, 253-265.

Donald, A. H., Charles, R. C. (2016). Matching and Behavioral Contrast in a Two-Option Repeated Investment Simulation. Managerial and Decision Economics, 37, 4-5, 294-305.

Eisenberger, R., Fasolo, P., Davis, V., \& La Mastro. (1990). Perceived organizational support and employee diligence, commitment, and innovation. Journal of Applied psychology 71(1), 51-59. https://doi.org/10.1037/0021-9010.75.1.51

Eisenberger, R., Huntington, R., Hutchison, S., \& Sowa, D. (1986). Perceived organizational

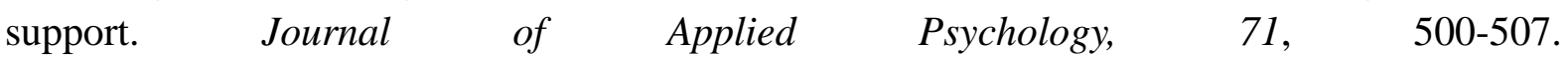
https://doi.org/10.1037/0021-9010.71.3.500

Erdogan, B., \& Enders, J. (2007). Support from the top: supervisors' perceived organizational support as moderator of leader-member exchange to satisfaction and performance relationship. Journal of Applied Psychology, 92(2), 321-330. https://doi.org/10.1037/0021-9010.92.2.321

Farh J. L., Hackett, R., \& Liang, J. (2007). Individual-level cultural values as moderators of perceived organizational support, employee outcome relationships in china: comparing the effects of power distance and traditionality. Academy of management journal, 50(3), 715-729. https://doi.org/10.5465/amj.2007.25530866

Farrukh, M., Chong, W. Y., Mansori, S., \& Ravan, R. S. (2017). Intrapreneurial behaviour: the role of organizational commitment. World Journal of Entrepreneurship, Management and Sustainable Development, 13(3), 243-256. https://doi.org/10.1108/WJEMSD-03-2017-0016

Farrukh, M., Khan, A. A., Khan, A. A., Shahid, K. M., Shahid, K. M., Ravan, R. S., ... \& Soladoye, B. S. A. (2017). Entrepreneurial intentions: the role of family factors, personality traits and self-efficacy. World Journal of Entrepreneurship, Management and Sustainable Development, 13(4), 303-317. https://doi.org/10.1108/WJEMSD-03-2017-0018

Farrukh, M., Wei, Y. C., \& Abdallah, A. N. O. (2016). Organizational commitment: Does religiosity matter? Cogent Business \& Management, 3(1), 1-10. https://doi.org/10.1080/23311975.2016.1239300

Farrukh, M., Ying, C. W., \& Mansori, S. (2017). Organizational commitment: an empirical analysis of personality traits. Journal of Work-Applied Management, 9(1), 18-34. https://doi.org/10.1108/JWAM-12-2016-0026

Farrukh, M., Ying, C., \& Mansori, S. (2016). Intrapreneurial behavior: an empirical investigation of personality traits Research issue. Management \& Marketing. Challenges for the Knowledge Society, 11(4), 597-609. 
https://doi.org/10.1515/mmcks-2016-0018.Introduction

Feldman. (1985). Careers in Organizations: Recent Trends and Future Directions. Journal of Management, 15, 135-156. https://doi.org/10.1177/014920638901500202

Fornell, C., \& Larcker, D. F. (1981). Evaluating Structural Equation Models with Unobservable Variables and Measurement Error. Journal of Marketing Research (18:1), 39-50. https://doi.org/10.2307/3151312

Foster, C., Punjaisri, K., \& Cheng, R. (2010). Exploring the relationship between corporate, internal and employer branding. Journal of Product \& Brand Management, 19(6), 401-409. https://doi.org/10.1108/10610421011085712

Gaskell, C. (2001). Employee's motivation Strategies established staff values transform your life. Published by: Thorsons. Pub. Date: 03.12.01. Imprint: Thorsons, ISBN: 978-0-00-713098-6.

Gouldner, A. W. (1960). The norm of reciprocity: a preliminary statement. American sociological review, 25, 161-178. https://doi.org/10.2307/2092623

Guiyao, T., Bingjie, Y., Fang, L. C., \& Yang, C. (2017). High-performance work system and employee creativity: The roles of perceived organisational support and devolved management, Personnel Review, 46(7),1318-1334. https://doi.org/10.1108/PR-09-2016-0235

Hackman, J. R., \& Lawler, E. E. (1971). Employee reactions to job characteristics. Journal of Applied Psychology, 55, 259-286. https://doi.org/10.1037/h0031152

Hair Jr, J. F., Hult, G. T. M., Ringle, C., \& Sarstedt, M. (2016). A primer on partial least squares structural equation modeling (PLS-SEM). Sage Publications.

Hair, J. F., Black, W. C., Babin, B. J., \& Anderson, R. E. (2010). Multivariate data analysis (7th ed.). Englewood Cliffs: Prentice Hall.

Hair, J. F., Ringle, C. M., \& Sarstedt, M. (2011). PLS-SEM: indeed a silver bullet. Journal of Marketing Theory and Practice, 19(2), 139-151. https://doi.org/10.2753/MTP1069-6679190202

Hair, J., Hult, T. G., Ringle, C., \& Sarsted, M. (2014). PARTIAL LEAST SQUARES STRUCTURAL EQUATION MODELING ( PLS-SEM ).

Hannif, Z., Burgess, J., \& Connell, J. (2008). Call Centre and the quality of work Life: Towards a research agenda. Journal of Industrial Relations, 50(2), 271-284. https://doi.org/10.1177/0022185607087902

Hayward. M. L. A., \& Rindova, T. G. (2004). Believing One's own Press: The causes and consequences of CEO celebrity. Strategic Management Journal, 25(7),637-653. https://doi.org/10.1002/smj.405

Hekman, D. R., Steensma, H. K., Bigley, G. A., \& Hereford, J. F. (2009). Combined Effects of Organizational and Professional Identification on the Reciprocity Dynamic for 
Professional Employees. Academy of Management Journal, 52(3). https://doi.org/10.5465/amj.2009.41330897

Hensler. J., \& Chin. W. W., (2010). A comparison fo approaches for the analysis of interaction effects between latent variables using partial least square path modeling. Structural Equation Modeling (pp.17,82--109). https://doi.org/10.1080/10705510903439003

Herbert, M. (1975). The pay for performance dilemma, organizational dynamics, 39-50.

Herpen, V. M., Praag, V. M., \& Cools, K. (2003). The effects of performance measurement and compensation on Motivation an empirical Study. De Economist, 153(3), 2005; Netherlands. https://doi.org/10.2139/ssrn.417355

Hertzberg, F. (2003). One more Time: How do you motivate employees? On point enhanced edition, Harvard Business Review, 81(1), 87-96.

Hollenbeck, N., \& Wright, G. (1993). Human Resources Management, Gaining a competitive Advantage 4th Edition, New York. 458-459. http://www.economist.com/node/5220660.

Hutchison, S., Sowa, R. D., \& Eisenberger, R. H. (1986). Perceived organizational support. Journal of Applied psychology, 71(3), 500-507. https://doi.org/10.1037/0021-9010.71.3.500

Jared, D., \& Harris, (2008). What's wrong with executive compensation? Journal of Business Ethics, 84.

Jean, C. B., Isabelle, D., Nicola, D., Carlos, F., Luigi, F., Robert, L., \& Kurt, V. L. Unpublished (2003). Managing labor market related risks in Europe: Policy implications. Unpublished.

Jean, P. M., \& Gilles, D. (2006). Quality of Work Life: Theoretical and Methodological Problems, and Presentation of a New Model and Measuring Instrument. Social Indicators Research, 77(2), 333-368. Published by: Springer Stable. Online URL: http://www.jstor.org/stable/27522585 . Accessed on 18 August 2009 05:23.

Kelly, G. A. (1955). The psychology of personal constructs. New York: Norton. Reprinted by Routledge (London), 1991.

Kuvaas, B. (2006). Work performance, affective commitment, and work motivation: the roles of pay administration and pay level. Journal of Organizational Behavior, 27(3), 365-85. https://doi.org/10.1002/job.377

Lazear E. P (1999). Personnel Economics: Past Lessons and Future Directions. Journal of Labor Economics, 17(2),199-236. https://doi.org/10.3386/w6957

Marinko, Š., Katarina, K., \& Katarina, J. J. (2015). Sustainability of Employee Productivity as a Presumption of Sustainable Business Journal of Economic Research. 26, 311-330. https://doi.org/10.1037/a0015852

Mello, \& Jaffery. (2005). Strategic Human Resource Management, 2nd Edition, southeastern, Thomos corporation, USA, 494-496. 
Minnesota Studies in Vocational Rehabilitation (1967). Manual for the minnesota satisfaction questionnaire. weiss, david j.; dawis, rene v.; england, george w. Minnesota Studies in Vocational Rehabilitation, 22,120.

O'Neill, O. A. (2009). Exploring relationships among anger, perceived organizational support, and workplace outcomes. Journal of Occupational Health Psychology, 14(3), 318-333.

Ohen, K., \& Sela. (2008). Optimal rewards in contests RAND. Journal of Economics, 39(2), 434.451. Online available at: http://www.jstor.org/stable/249764. Accessed on june 22, 2010 00:56.

Pallant, J. (2007). SPSS survival manual: A step by step guide to data analysis using SPSS for windows (3rd ed.). Buckingham: Open University Press.

Qunchao, L., \& Xinli, X. (2017) Community involvement and place identity: the role of perceived values, perceived fairness, and subjective well-being, Asia Pacific Journal of Tourism Research, 22(9), 951-964. https://doi.org/10.1080/10941665.2017.1345772

Rhodes L., \& Eisenberger, R. (2002). Perceived organizational support, a review of the $\begin{array}{llll}\text { literature. Journal of applied } & \text { 8sychology, 698-714. }\end{array}$ https://doi.org/10.1037/0021-9010.87.4.698

Riaz, Q., Farrukh, M., Rehman, S. U., \& Ishaque, A. (2016). Religion and entrepreneurial intentions: an empirical investigation. International Journal of Advanced and Applied Sciences, 3(9), 31-36. https://doi.org/10.21833/ijaas.2016.09.006

Rigdon, E. E., Ringle, C. M., \& Sarstedt, M. (2010). Structural modeling of heterogeneous data with partial least squares. In Review of marketing research (pp. 255-296). Emerald Group Publishing Limited. https://doi.org/10.1108/S1548-6435(2010)0000007011

Ringle, C. M., Wende, S., \& Becker, J. M. (2015). SmartPLS 3 - Bönningstedt: SmartPLS”, available at: www.smartpls.com [Google Scholar].

Sarah, S. (2007). Crossing the generational divide: engaging "young" employees in your organization. Development and Learning in Organizations, 21(2).

Shahzad, A. I. (2008). Antecedents of Compensation and relationship among Compensation, Motivation and Organizational profitability. Journal of American Academy of Business, Cambridge, The Business Review, Cambridge (BRC), 10(2), 146-153.

Shahzad, I. A., Bhatti, K. K., \& Khan, G. K. (June 2007). Impact of Technological changes on Human Resources Development Practices. International Review of Business Research Papers, 3(2), 400-419.

Shahzad, I. A., Farrukh, M., Kanwal, N., \& Sakib, A. (2018). Decision-making participation eulogizes probability of behavioral output; job satisfaction, and employee performance (evidence from professionals having low and high levels of perceived organizational support). World Journal of Entrepreneurship, Management and Sustainable Development. https://doi.org/10.1108/WJEMSD-01-2018-0006 


\section{Macrothink}

International Journal of Human Resource Studies

ISSN 2162-3058 2018, Vol. 8, No. 3

Shore, L. M,. \& Shore, T. H. (1995). Perceived organizational support and organizational justice. In Cropanzano, R.S. \& K.M. Kacmar (Eds.). Organizational politics, justice, and support: Managing the social climate of the workplace,149-164. Westport, CT: Quorum

Sigvard, R., Fleming, N., \& Arnald, S.T. (1983). Some social psychological effects of direct and indirect participation in ten Swedish companies. Organization studies, 4(3), 243-259. https://doi.org/10.1177/017084068300400303

Thomas, P. Jr. (1977). Employee compensation and Incentive plans (New York; Free Press.

Tucker, S., Chmiel, N., Turner, N., Hershcovis, M., Sandy, S., \& Chris, B. (2008). Perceived organizational support for safety and employee voice: the mediating role of coworker support for safety. Journal of Occupational Health Psychology, 13(4),319-330. https://doi.org/10.1037/1076-8998.13.4.319

Vroom, V. (1964). Work and Motivation, Wiley, New York.

Witt, L. A., \& Carlson, D. S. (Oct, 2006). The work-family interface and job performance: moderating effects of conscientiousness and perceived organizational support. Journal of Occupational Health Psychology, 11(4),343-357. https://doi.org/10.1037/1076-8998.11.4.343

www.osec.ch on June 28, 2011 http://budget.par.com.pk/economic-survey/2014-15/.

Yu, R. H. (2011). Work-family conflict and job satisfaction in stressful working environments: The moderating roles of perceived supervisor support and internal locus of control. International Journal of Manpower, 32(2).

Zhao, X., Lynch Jr., J. G., \& Chen, Q. (2010). Reconsidering Baron and Kenny: Myths and Truths about Mediation Analysis. Journal of Consumer Research, 37(2), 197-206. https://doi.org/10.1086/651257

\section{Copyright Disclaimer}

Copyright for this article is retained by the author(s), with first publication rights granted to the journal.

This is an open-access article distributed under the terms and conditions of the Creative Commons Attribution license (http://creativecommons.org/licenses/by/4.0/). 